\title{
Global Risk and Demand for Gold by Central Banks
}

\section{Balagopal Gopalakrishnan \\ Sanket Mohapatra}

W. P. No. 2017-01-01

January 2017

The main objective of the working paper series of the IIMA is to help faculty members, research staff and doctoral students to speedily share their research findings with professional colleagues and test their research findings at the pre-publication stage. IIMA is committed to maintain academic freedom. The opinion(s), view(s) and conclusion(s) expressed in the working paper are those of the authors and not that of IIMA.

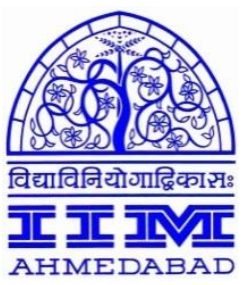

INDIAN INSTITUTE OF MANAGEMENT

AHMEDABAD-380 015

INDIA 


\title{
Global Risk and Demand for Gold by Central Banks
}

\author{
Balagopal Gopalakrishnan and Sanket Mohapatra \\ Indian Institute of Management, Ahmedabad
}

\begin{abstract}
This paper examines the influence of global risk on the holding of gold by central banks based on annual data for 100 countries during 1990-2015. We use a dynamic panel generalized method of moments (GMM) model to estimate this effect, controlling for a variety of domestic factors. Consistent with portfolio diversification and perception of gold as a safe asset, we find that the gold holdings of central banks increase in response to higher global risk. This effect is larger for high-income countries than for developing countries. Moreover, greater capital account openness is associated with a stronger response of central banks' gold holding to global risk, while a higher ratio of overall reserves to imports is associated with a weaker response. We also find evidence that the sensitivity depends on whether the currency regime followed is fixed or floating, with higher responsiveness in the case of fixed rate regimes. The baseline results are robust to alternate estimation methods, exclusion of crisis years, active and passive management of gold reserves and additional controls. These findings suggest that central banks adjust their gold holdings in response to changes in global risk conditions, with the magnitude of response depending on reserve management capacity and country-specific vulnerabilities.
\end{abstract}

Keywords: gold, central banks, global risk diversification, capital account openness, flight to quality

JEL Codes: G11, F31, F33

\footnotetext{
* We thank Prof. Arvind Sahay (Head, India Gold Policy Center at IIM Ahmedabad) for useful comments and suggestions. The views expressed in this paper are solely those of the authors and do not represent the views of the Indian Institute of Management, Ahmedabad. Contact emails: balagopalg@iima.ac.in, sanketm@iima.ac.in.
} 


\section{Introduction}

Gold has been a staple of central bank reserves since the gold standard era when the issue of domestic currency was fully backed by gold (Eichengreen, 2005; Officer, 2010). Since the collapse of the Bretton Woods system in the early 1970s, gold has gradually been replaced by a variety of currencies and the share of gold in international reserves has gradually declined (O’Connor, Lucey, Batten, \& Baur, 2015). In recent years, gold has accounted for a relatively small share of overall international reserves of central banks, declining from 16.5 percent in 1990 to 6.01 percent by 2015 (Figure 1). Yet due to the perception of gold as a safe asset particularly during times of heightened global uncertainty, it remains an important component of the portfolio of central banking assets (O'Connor et al., 2015). Moreover, since gold issuance is not controlled by any one government or central bank, the value of gold cannot be influenced by political decisions or by the solvency of any individual institution (Rossi, 2013).

Risk plays a key role in the demand for financial assets and precious metals such as gold. Several studies have examined the role of gold in portfolio diversification of investors and households (Beckmann, Berger, \& Czudaj, 2015; Bredin, Conlon, \& Poti, 2015; Dempster \& Artigas,2009).

\section{Figure 1: Gold reserves as share of overall reserves and global risk}

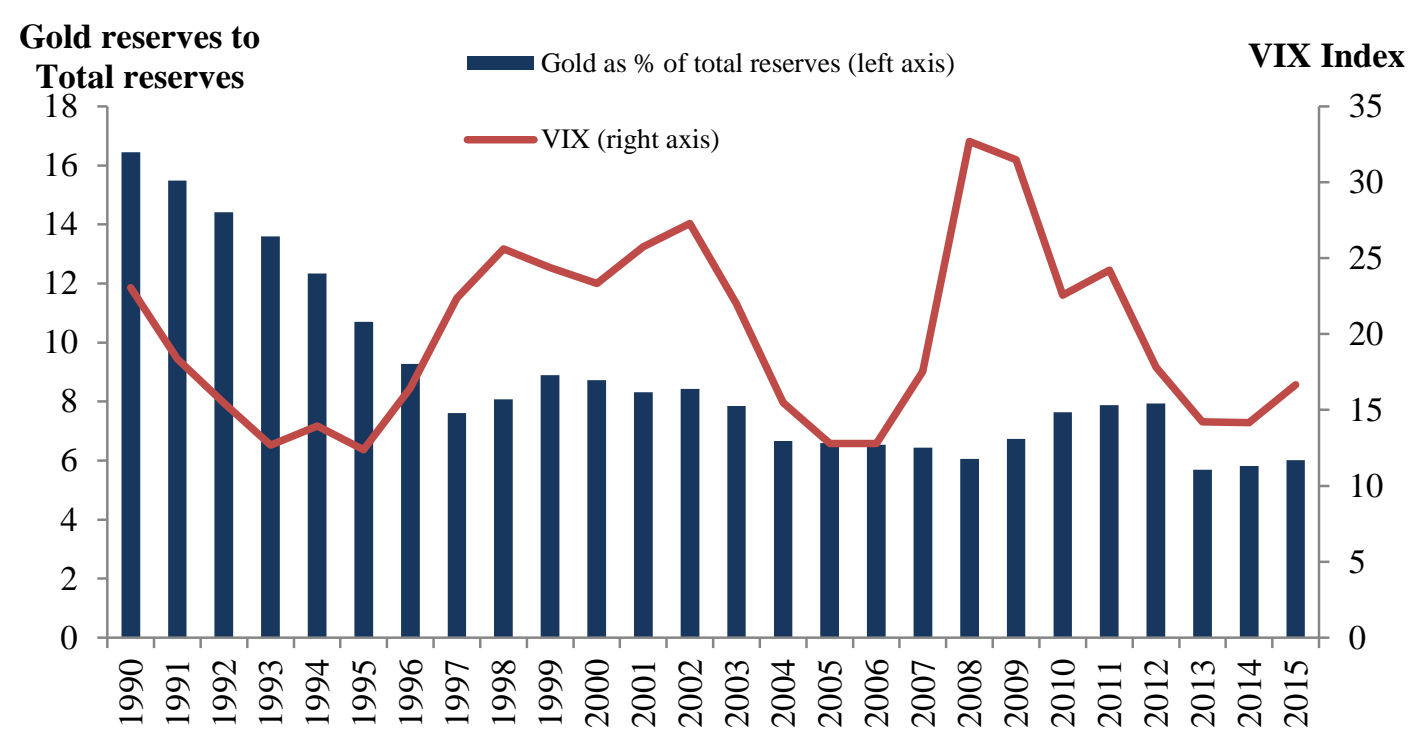

Source: IMF and CBOE 
The demand for gold typically rises during "risk-off" periods when there is a "flight to quality" (Baur \& Lucey, 2010; Baur \& McDermott, 2010). Active management of gold in the central bank reserves portfolio had been proposed to ensure better diversification of the risks in their portfolios (European Central Bank, 2004).

Gold holdings of institutional investors also suggest that it is beneficial to hold some gold in investment portfolios (Emmrich \& McGroarty, 2013). A World Gold Council (2016) study finds that gold is the third most liquid asset in the securities market behind US treasury securities and Japanese government bonds. It further finds that gold has been used as collateral by central banks during periods of crisis over the last four decades, and hence its demand is expected to depend on diversification motives and global risk conditions. Gold is considered one of the better hedges against inflation, and this effect is evidenced in a study done on data from last two centuries in the US and UK (Bampinas \& Panagiotidis, 2015). The results of the study indicate that the real price of gold has mean-reverting properties and acts as an effective hedge against inflation.

Since central banks typically treat gold as a safe component of their portfolio, their demand for gold is expected to depend on diversification motives and on global risk conditions. A recent study examined the domestic factors which account for an increase in the gold reserves held by the Reserve bank of India (Ghosh, 2016).

Our paper contributes to the nascent literature on the demand for gold by central banks. To our knowledge, this is the first study to conduct a cross-country empirical analysis of gold holdings by central banks that focuses specifically on the role of global risk. Secondly, our sample of 100 countries (spread across 41 high-income countries and 59 developing countries) is significantly larger than other studies which have focused on determinants of gold reserves in a single country (Ghosh, 2016) or small group of relatively homogenous countries (Aizenman \& Inoue, 2013; Oktay, Öztunç, \& Serİn, 2016). Finally, our work considers differential effects of vulnerabilities such as reserve adequacy and income status.

We find a statistically and economically significant effect of global risk on the gold holdings of central banks after controlling for a variety of country-specific factors and global gold prices. The effect is stronger when capital account openness is higher and reserve adequacy (the share of overall reserves in GDP) is lower, suggesting that central banks in countries that may be 
vulnerable to sudden "stops" in capital outflows (Reinhart \& Calvo, 2000) hold a larger amount of gold in their overall portfolio. We conduct several robustness checks with alternative estimation methods, exclusion of crisis years, considering gold as a proportion of GDP as the dependent variable as in Aizenman \& Inoue (2013) and the inclusion of real exchange rate changes. The results obtained are consistent with the baseline results.

The next section discusses the data and methodology. This is followed by a discussion of results and analysis, and the subsequent section concludes.

\section{Data and Methodology}

\subsection{Data description}

A comprehensive database of central banks' gold holdings and macroeconomic and institutional variables was constructed at annual frequency. Gold holdings of central banks in 100 countries were obtained from the International Monetary Fund's (IMF) International Financial Statistics (IFS) database. Macroeconomic variables were obtained from the World Development Indicators (WDI) and IMF IFS.

Global risk has been recognized as a driver of a global financial cycle (Miranda-Agrippino \& Rey, 2015). A widely used measure of global risk is the Chicago Board of Options Exchange's VIX index (Ciarlone, Piselli, \& Trebeschi, 2009) which we use in this study. The VIX risk index has been associated with overall financial flows (Nier, Saadi-Sedik, \& Mondino, 2014), leverage and risk-taking by banks ( Bruno \& Shin, 2015). Popularly known as the investor fear index, VIX broadly captures the investor sentiment prevalent in the global economy (Bacchetta \& Van Wincoop, 2013). This measure has been used widely in the literature as a proxy for global risk (Garcia, Ortiz, \& Cowan, 2006; Jubinski, Lipton, \& Joseph, 2013; Sari, Soytas, \& Hacihasanoglu, 2011).

In addition to the global VIX index, the country-specific determinants of gold reserves can include capital account openness, trade openness, GDP per capita, GDP growth, inflation, price of gold (in 2010 US dollars), Institutional Investor Risk (IIR) index, and the ratio of private credit to GDP. Higher capital account openness is usually associated with greater vulnerability to 
changes in gross capital flows (Roveda \& Rosselli, 2003), hence may be associated with larger gold holdings as a hedge. Capital account openness and trade openness have been used in several prior studies on the determinants of central bank reserve holdings (Lane \& Burke, 2001; MarcAndre \& Parent, 2005; Obstfeld, Shambaugh, \& Taylor, 2009). GDP per capita is used as a control for the relative capacity of countries to accumulate gold reserves and is a measure of economic size which is considered as one of the determinants of reserve holdings (Marc-Andre \& Parent, 2005).

\section{Table 1: Data definitions and sources}

\begin{tabular}{|c|c|c|}
\hline Variable & Definition and Construction & Data sources \\
\hline Gold reserves to total reserves & $\begin{array}{l}\text { Ratio of gold reserves to overall } \\
\text { reserves(both values in million current } \\
\text { US dollars) }\end{array}$ & $\begin{array}{l}\text { IMF International } \\
\text { Statistics (IFS) }\end{array}$ \\
\hline VIX & $\begin{array}{l}\text { Global risk index (Index of implied } \\
\text { volatility of S\&P 500) }\end{array}$ & $\begin{array}{l}\text { Chicago Board Options Exchange } \\
\text { (CBOE) }\end{array}$ \\
\hline GDP per capita & $\begin{array}{l}\text { Gross domestic product per capita in } \\
\text { nominal US dollars }\end{array}$ & World Development Indicators(WDI) \\
\hline GDP growth & $\begin{array}{l}\text { Growth of Gross Domestic Product of } \\
\text { an economy measured annually. }\end{array}$ & IMF IFS \\
\hline Institutional Investor Rating & $\begin{array}{l}\text { Rating of sovereign default risk, based } \\
\text { on institutional investors perception of } \\
\text { the risk }\end{array}$ & Institutional Investor \\
\hline $\begin{array}{l}\text { Developing \& High-income } \\
\text { countries }\end{array}$ & $\begin{array}{l}\text { Classification of the countries based } \\
\text { on their income }\end{array}$ & World Bank classification \\
\hline Private credit to GDP & $\begin{array}{l}\text { Domestic credit to private sector as a } \\
\text { share of GDP }\end{array}$ & WDI \\
\hline Capital account openness & $\begin{array}{l}\text { Measure of capital account openness } \\
\text { to fund flows from foreign countries }\end{array}$ & $\begin{array}{l}\text { Chinn and Ito (Chinn \& Ito, 2006) } \\
\text { index }\end{array}$ \\
\hline Trade openness & $\begin{array}{l}\text { Ratio of total exports and imports to } \\
\text { gross domestic product. This } \\
\text { measures the relative openness of the } \\
\text { economy to world trade. }\end{array}$ & IMF Balance of Payments statistics \\
\hline Inflation & $\begin{array}{l}\text { Measure of nominal price (Consumer } \\
\text { Price Index) changes in an economy }\end{array}$ & IMF IFS \\
\hline Gold Price & $\begin{array}{l}\text { The price of the gold in dollars per } \\
\text { troy ounce ( } 2010 \text { US dollars) }\end{array}$ & World Bank commodity price data \\
\hline
\end{tabular}

Recent literature indicates that reserve accumulation is a consequence of a growth strategy undertaken by the countries adopting a growth strategy and that developing countries which grow faster accumulate more international reserves (Benigno \& Fornaro, 2012; Cheng, 2015). 
GDP growth is used as a control for the propensity to accumulate gold reserves by countries that engage in competitive hoarding of reserves, a phenomenon that started in the early 1990s as an aftermath of both export promotion and credit subsidization motives (Aizenman \& Lee, 2008). In order to control for the depth of domestic financial markets which can contribute to reserve holdings (Lane \& Burke, 2001), we have used the ratio of private credit to GDP as a proxy for the level of financial development (Svirydzenka, 2016). In order to capture country-specific risks, we use the Institutional Investors Rating (IIR). Gold price in real terms is also used as one of the explanatory variable to control for price effect on central banks' gold demand in some specifications.

Table 2: Summary statistics

\begin{tabular}{lccccc}
\hline Variables & Count & Mean & SD & Min & Max \\
\hline Gold to total reserves (\%) & 1,814 & 9.95 & 16.58 & 0.00 & 90.99 \\
VIX & 1,814 & 20.30 & 6.04 & 12.39 & 32.69 \\
GDP growth (\%) & 1,814 & 3.86 & 3.64 & -14.76 & 33.75 \\
Trade openness (\%) & 1,814 & 83.11 & 55.14 & 13.94 & 442.54 \\
Capital account openness & 1,814 & 61.13 & 35.53 & 0.00 & 100.00 \\
Private credit to GDP (\%) & 1,814 & 62.44 & 48.36 & 0.19 & 312.15 \\
Log GDP per capita & 1,814 & 9.05 & 1.37 & 5.39 & 11.68 \\
Log IIR & 1,814 & 3.88 & 0.50 & 2.02 & 4.57 \\
Inflation & 1,814 & 5.42 & 5.00 & -13.14 & 25.00 \\
Log Gold price & 1,814 & 6.41 & 0.50 & 5.85 & 7.35 \\
\hline
\end{tabular}

\subsection{Empirical specification}

The estimation equation for the determinants of gold holdings by central banks can be expressed as:

$$
G_{i t}=\delta_{1} G_{i t-1}+\delta_{2} V I X_{t-1}+\delta_{3} X_{i t-1}+\mu_{i}+\varepsilon_{i t}
$$

where $G_{i t}$ is gold reserves as a share of overall international reserves, VIX $X_{t-1}$ is the global VIX index, $X_{i t-1}$ is a vector of macroeconomic and institutional variables, $\mu_{i}$ is a country-specific intercept, and $\varepsilon_{i t}$ is the error term. As discussed above, the vector of macroeconomic and institutional variables includes GDP per capita, GDP growth, capital account openness, trade openness, institutional investors country ratings, inflation and private credit to GDP. In some 
alternative specifications, we include the international gold price (in constant 2010 US dollars) as an additional explanatory variable. Summary statistics of all the variables used is as shown in table 2 .

Since equation (1) includes a lagged dependent variable, the coefficients obtained from ordinary least squares with fixed effects (OLS-FE) are subject to dynamic panel bias popularly known as Nickell bias (Nickell, 1981). ${ }^{1}$ In order to account for Nickell bias, dynamic panel generalized method of moments (GMM) estimators are used to estimate equation (1). We use two types of dynamic panel estimators - a difference GMM (DGMM) estimator proposed by Arellano \& Bond (1991) and the SGMM estimator of Arellano \& Bover (1995). These panel estimators are suitable for panels with few time periods and a large number of individual entities.

While DGMM uses the moment conditions from the estimated first differences of the error terms, SGMM uses both the estimates first difference and level residuals for the moment conditions. SGMM is more efficient given the larger number of instruments possible with the addition of level residuals in the moment conditions (Roodman, 2009). We use a collapsed instrument matrix to estimate the results. We present the results of both the DGMM and SGMM estimators for the baseline regression, but use SGMM for our subsequent analysis in view of its higher efficiency.

Acknowledging potential endogeneity of some of our country-specific variables to central banks' gold holding - such as capital account openness, GDP growth (Bussière, Cheng, Chinn, \& Lisack, 2015), price (Baur, 2016; Chen, Lee, \& You, 2014) and IIR — we control for the same by using a system generalized method of moments (SGMM) estimator, which allows for potentially endogenous regressors. We have controlled for inflation in the analysis, but exclude periods of high annual inflation exceeding 25 percent. Furthermore, we lag all the explanatory variables by one period to avoid contemporaneous reverse feedback effects.

\footnotetext{
${ }^{1}$ Baseline results for OLS-FE model indicate that the relationship between lagged VIX and gold to total reserves is significant and the direction is consistent with the dynamic GMM results.
} 


\section{Results}

\subsection{Baseline model}

In the baseline model based regression, as seen in the results in Table 3, there is a significant impact of the lagged VIX variable on the level of gold reserves to overall reserves in an economy after controlling for other variables which affect reserve management in central banks. The results are consistent across the specification used to evaluate this relationship. In all the variants of the baseline specification, the lagged dependent variable has a consistent and significant value, indicating serial correlation in central bank reserve holdings, as seen in preliminary tests.

The coefficient on capital account openness supports the hypothesis that a more open economy in terms of capital flows tend to be more prone to volatile capital flows as compared to a relatively closed economy. This would lead to such economies holding higher gold reserves in their portfolio against potential vulnerabilities. The relationship between trade openness and gold to total reserves is consistently negative in the results indicating its effect on non-gold reserves. ${ }^{2}$

The accumulation strategy followed by faster-growing countries such as the developing countries tend to also affect the growth in gold holdings as a percentage of overall reserves, and the relationship is positive as indicated in the baseline results. While gold is expected to act as a hedge against inflation, such an effect is not seen in the results for central bank gold reserves as indicated below. The results in columns (3) and (4) indicate that with or without controlling for the gold price effect, the gold reserves are sensitive to the global risk measure. As indicated in the literature review above, gold price may be endogenous to the demand for gold and we have considered this in the GMM estimation. However, the sign and significance of the effect of VIX on gold reserves is consistent with or without the gold price control.

On average, holding all other variables constant, a unit change in the global risk measure increases gold reserves to overall reserves by 6.7 basis points. An implication of this result is that a one standard deviation increase in the global risk measure (equivalent to 6 units increase in VIX index) increases the share of gold reserves in overall reserves by 4.2 percent relative to the

2 Some studies regarding international reserves have found a positive relationship between trade openness and reserves excluding gold(Lane \& Burke, 2001). 
mean.

Table 3: Determinants of gold reserves in overall central bank reserves: Baseline results

\begin{tabular}{|c|c|c|c|c|}
\hline & $\begin{array}{c}\text { DGMM } \\
(1)\end{array}$ & $\begin{array}{c}\text { DGMM } \\
(2) \\
\end{array}$ & $\begin{array}{c}\text { SGMM } \\
\text { (3) }\end{array}$ & $\begin{array}{c}\text { SGMM } \\
(4)\end{array}$ \\
\hline Gold to total reserves t-1 $_{\text {t }}$ & $\begin{array}{c}0.924 * * * \\
(0.066)\end{array}$ & $\begin{array}{c}0.903 * * * \\
(0.070)\end{array}$ & $\begin{array}{c}0.908 * * * \\
(0.077)\end{array}$ & $\begin{array}{c}0.893 * * * \\
(0.056)\end{array}$ \\
\hline VIX $_{t-1}$ & $\begin{array}{c}0.075 * * \\
(0.031)\end{array}$ & $\begin{array}{c}0.066 * * \\
(0.033)\end{array}$ & $\begin{array}{c}0.075 * * * \\
(0.025)\end{array}$ & $\begin{array}{c}0.067 * * \\
(0.033)\end{array}$ \\
\hline GDP growth t-1 & $\begin{array}{c}0.320 * * \\
(0.142)\end{array}$ & $\begin{array}{l}0.243 * \\
(0.128)\end{array}$ & $\begin{array}{c}0.403 * * \\
(0.160)\end{array}$ & $\begin{array}{c}0.299 * * \\
(0.123)\end{array}$ \\
\hline Trade openness $_{\mathbf{t}-\mathbf{1}}$ & $\begin{array}{c}-0.068 * * \\
(0.034)\end{array}$ & $\begin{array}{l}-0.042 \\
(0.028)\end{array}$ & $\begin{array}{l}-0.054 \\
(0.037)\end{array}$ & $\begin{array}{c}-0.046 * \\
(0.027)\end{array}$ \\
\hline Capital account openness $s_{t-1}$ & $\begin{array}{c}0.082 * * * \\
(0.029)\end{array}$ & $\begin{array}{l}0.042 * \\
(0.025)\end{array}$ & $\begin{array}{l}0.038 * \\
(0.021)\end{array}$ & $\begin{array}{c}0.055 * * \\
(0.024)\end{array}$ \\
\hline Private credit to $\mathrm{GDP}_{\mathrm{t}-\mathbf{1}}$ & $\begin{array}{c}0.011 \\
(0.035)\end{array}$ & $\begin{array}{l}-0.016 \\
(0.033)\end{array}$ & $\begin{array}{c}0.034 \\
(0.031)\end{array}$ & $\begin{array}{c}0.015 \\
(0.024)\end{array}$ \\
\hline $\log _{\text {GDP per capita }}$ t-1 & $\begin{array}{c}0.869 \\
(1.545)\end{array}$ & $\begin{array}{c}1.88 \\
(1.728)\end{array}$ & $\begin{array}{c}0.606 \\
(1.020)\end{array}$ & $\begin{array}{l}-0.348 \\
(2.189)\end{array}$ \\
\hline $\log \operatorname{IIR}_{t-1}$ & $\begin{array}{c}3.728 \\
(2.497)\end{array}$ & $\begin{array}{l}4.340 * \\
(2.305)\end{array}$ & $\begin{array}{c}0.356 \\
(2.965)\end{array}$ & $\begin{array}{c}1.643 \\
(3.093)\end{array}$ \\
\hline Inflation $_{\mathbf{t}-1}$ & $\begin{array}{c}0.02 \\
(0.022)\end{array}$ & $\begin{array}{c}0.014 \\
(0.017)\end{array}$ & $\begin{array}{c}0.005 \\
(0.093)\end{array}$ & $\begin{array}{c}0.032 \\
(0.114)\end{array}$ \\
\hline Log Gold price $_{t-1}$ & & $\begin{array}{c}-0.664 \\
(1.064)\end{array}$ & & $\begin{array}{c}0.474 \\
(1.082)\end{array}$ \\
\hline Constant & & & $\begin{array}{c}-8.803 \\
(7.624)\end{array}$ & $\begin{array}{l}-8.322 \\
(8.000)\end{array}$ \\
\hline No. of obs. & 1,718 & 1,718 & 1,814 & 1,814 \\
\hline No. of instruments & 43 & 47 & 43 & 47 \\
\hline Hansen statistic & 32.402 & 34.557 & 33.586 & 44.844 \\
\hline $\operatorname{AR}(2)$ statistic & 1.080 & 1.069 & 0.451 & -0.107 \\
\hline Wald Chi-square & $564.745 * * *$ & $582.244 * * *$ & $307.969 * * *$ & 427.576 *** \\
\hline
\end{tabular}

Notes: The dependent variable is gold as a share of overall central bank reserves. Regressions are estimated using the systerm generalized methods of moments (SGMM) method with a collapsed instrument set. Heteroskedasticity and autocorrelation-robust Windmeijer-corrected standard errors are reported in parentheses. All regressions pass the Hansen test of over-identifying restrictions and the Arellano-Bond test for AR(2). *** Significant at 1\%, ** significant at 5\% and * significant at $10 \%$.

\subsection{Subsample estimations}

Table 4 captures the sensitivity of gold reserves to the global risk indicator for high-income and developing countries, for high and low capital account openness, for high or low total reserves and for high and low level of reserves coverage for months of imports. All the high and low measures are based on above the median and below the median values respectively.

The results in columns (1) and (2) indicate that high-income countries' portfolio management is more sensitive to VIX than that of developing countries. Given that such countries have advanced systems, access to relatively efficient financial markets and sophisticated risk 
management tools in their central banks, their portfolio management expected to be better as compared to that in developing countries.

Table 4: Global risk and country dependence: System GMM results for sub-samples

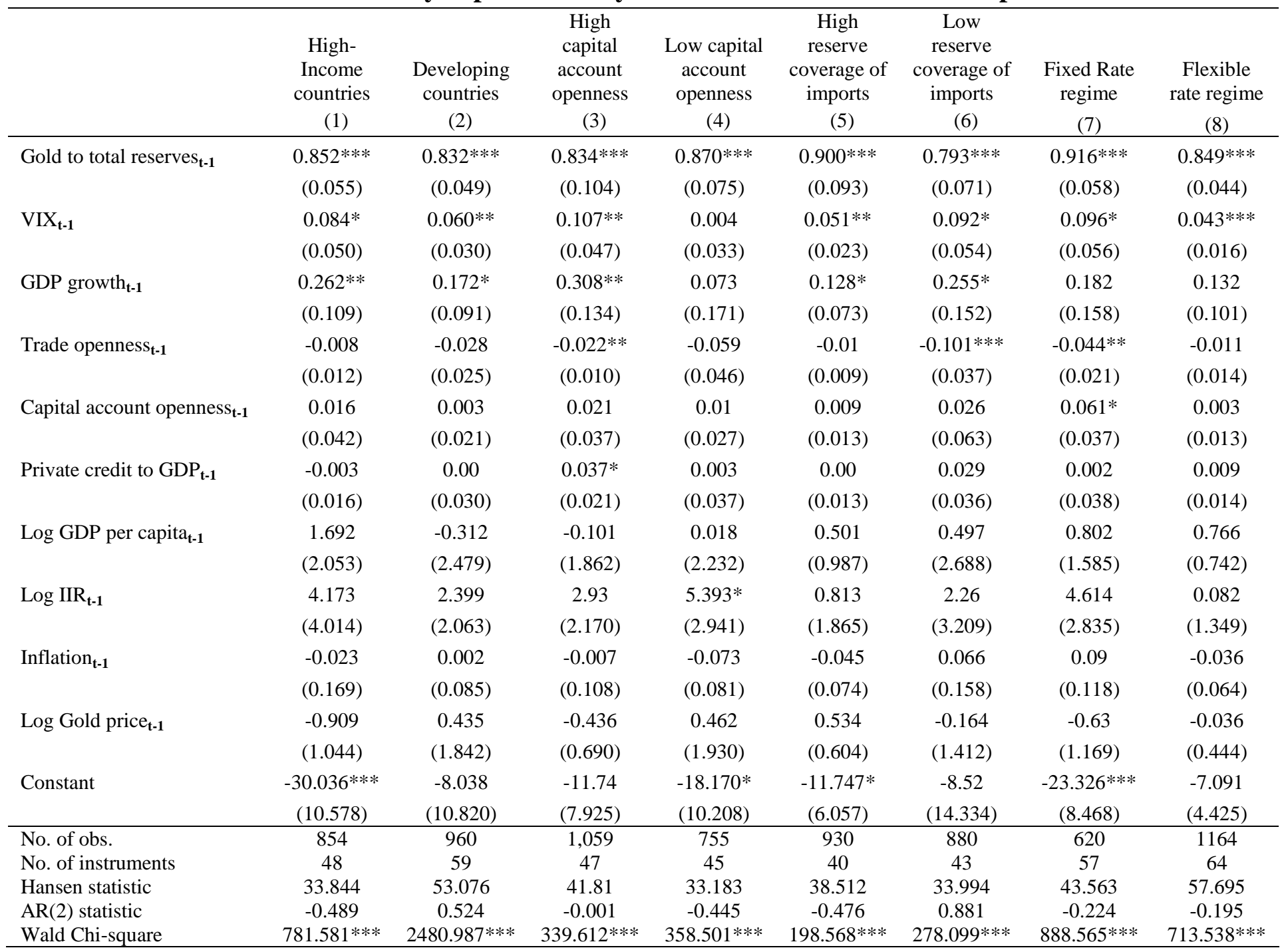

Notes: Column (1) includes 41 high-income countries and 59 developing countries. The dependent variable is gold as a share of overall central bank reserves. Regressions are estimated using the systerm generalized methods of moments (SGMM) method with a collapsed instrument set. Heteroskedasticity and autocorrelation-robust Windmeijer-corrected standard errors are reported in parentheses. All regressions pass the Hansen test of over-identifying restrictions and the Arellano-Bond test for AR(2). *** Significant at $1 \%, * *$ significant at $5 \%$ and $*$ significant at $10 \%$.

Countries with high capital account openness are vulnerable to transfer of risks from other geographies and could face capital flight in the event of domestic or external financial turmoil. The results in columns (3) and (4) indicate that such economies with higher capital account openness are more sensitive to global risk than countries with relatively less open capital 
accounts.

Similar vulnerability in terms of reserves coverage for month of imports (see table 4 columns (5) and (6)) indicate that those countries with lower levels of coverage are more vulnerable to global risks and hence manage their gold reserves portfolio as compared to those countries which are relatively comfortable in terms of the reserves coverage.

We check for the sensitivity of specific currency regime to hold a higher proportion of gold reserves to overall reserves in time of higher global risks and the results are in columns (7) and (8). The currency regimes with fixed regimes as per the Ilzetzki et al. (2010) classification exhibits higher sensitivity to holding gold reserves as a proportion of overall reserves as compared to relatively flexible exchange rate regimes. ${ }^{3}$

\subsection{Robustness check}

We test the robustness of the baseline results in five ways; using an alternate estimation methodology, avoiding financial crisis years, subsample by active and passive management periods, addition of change in the real effective exchange rate (REER) as a determinant, and using gold to GDP as the dependent variable.

Our first set of results, as indicated in table 5, obtained using a bias-corrected Least Squared Dummy Variables (LSDV) (Bruno, 2005) specification, is similar to the baseline results in terms of the sensitivity of the gold reserves to VIX. Following that, we test the sensitivity of gold reserves during the time period excluding the Global Financial Crisis years (2008 \& 2009). The results obtained for the non-crisis years in column (2) are similar to that in the full sample.

The next test checks whether the effect of VIX is prominent during country years when there is active management of gold reserves (which is close to $53 \%$ of the country years used for this study) or passive management of gold reserves. It has been evidenced in a recent study that gold holding changes in high-income countries are discrete stepwise changes and remains passive during other periods (Aizenman \& Inoue, 2013). The result in columns (3) and (4) indicates that it is the period of active management (change in quantity) of gold reserves that is driving the

\footnotetext{
${ }^{3}$ The exchange rate regime in 2010 (the latest available data) is extrapolated to the subsequent years. 
sensitivity of gold reserves to total reserves to VIX.

Table 5: Robustness check

\begin{tabular}{|c|c|c|c|c|c|c|}
\hline & $\begin{array}{l}\text { Bias corrected } \\
\text { Least Squared } \\
\text { Dummy } \\
\text { Variable } \\
\text { (1) }\end{array}$ & $\begin{array}{c}\text { Baseline model } \\
\text { without } \\
\text { financial crisis } \\
\text { years } \\
\text { (2) }\end{array}$ & $\begin{array}{l}\text { Baseline } \\
\text { model with } \\
\text { active } \\
\text { management } \\
\text { (3) }\end{array}$ & $\begin{array}{l}\text { Baseline } \\
\text { model with } \\
\text { passive } \\
\text { management } \\
\text { (4) }\end{array}$ & $\begin{array}{l}\text { Baseline } \\
\text { model with } \\
\text { change in } \\
\text { REER } \\
(5)\end{array}$ & $\begin{array}{l}\text { Model with } \\
\text { Gold to GDP } \\
\text { (\%) } \\
\text { (6) }\end{array}$ \\
\hline Gold to total reserves $t_{t-1}$ & $\begin{array}{c}0.828 * * * \\
(0.013)\end{array}$ & $\begin{array}{c}0.889 * * * \\
(0.075)\end{array}$ & $\begin{array}{c}0.968 * * * \\
(0.071)\end{array}$ & $\begin{array}{c}0.893 * * * \\
(0.078)\end{array}$ & $\begin{array}{c}0.909 * * * \\
(0.091)\end{array}$ & \\
\hline Gold to $\mathrm{GDP}_{\mathrm{t}-\mathbf{1}}$ & & & & & & $\begin{array}{c}0.823 * * * \\
(0.056)\end{array}$ \\
\hline VIX $_{t-1}$ & $\begin{array}{l}0.038 * \\
(0.021)\end{array}$ & $\begin{array}{c}0.056 * \\
(0.030)\end{array}$ & $\begin{array}{l}0.061 * \\
(0.034)\end{array}$ & $\begin{array}{c}0.04 \\
(0.033)\end{array}$ & $\begin{array}{c}0.088^{* *} \\
(0.038)\end{array}$ & $\begin{array}{c}0.009 * * * \\
(0.003)\end{array}$ \\
\hline GDP growth $_{\text {t-1 }}$ & $\begin{array}{c}-0.033 \\
(0.041)\end{array}$ & $\begin{array}{c}0.234 * * \\
(0.109)\end{array}$ & $\begin{array}{c}0.308 * * \\
(0.156)\end{array}$ & $\begin{array}{c}-0.03 \\
(0.079)\end{array}$ & $\begin{array}{c}0.261 * * \\
(0.123)\end{array}$ & $\begin{array}{l}-0.001 \\
(0.010)\end{array}$ \\
\hline Trade openness $t_{\mathbf{t}-\mathbf{1}}$ & $\begin{array}{c}-0.009 \\
(0.008)\end{array}$ & $\begin{array}{c}-0.046 \\
(0.030)\end{array}$ & $\begin{array}{l}-0.039 \\
(0.040)\end{array}$ & $\begin{array}{c}-0.042 * * \\
(0.021)\end{array}$ & $\begin{array}{l}-0.006 \\
(0.018)\end{array}$ & $\begin{array}{l}-0.001 \\
(0.001)\end{array}$ \\
\hline Capital account openness t-1 $_{1}$ & $\begin{array}{c}0.027 * * * \\
(0.007)\end{array}$ & $\begin{array}{c}0.053 * * * \\
(0.019)\end{array}$ & $\begin{array}{l}0.053^{*} \\
(0.031)\end{array}$ & $\begin{array}{c}0.054 \\
(0.041)\end{array}$ & $\begin{array}{c}0.007 \\
(0.028)\end{array}$ & $\begin{array}{c}0.002 \\
(0.002)\end{array}$ \\
\hline Private credit to $\mathrm{GDP}_{\mathrm{t}-\mathbf{1}}$ & $\begin{array}{c}0.008 \\
(0.007)\end{array}$ & $\begin{array}{c}0.007 \\
(0.019)\end{array}$ & $\begin{array}{c}0.023 \\
(0.037)\end{array}$ & $\begin{array}{l}-0.018 \\
(0.031)\end{array}$ & $\begin{array}{c}-0.009 \\
(0.024)\end{array}$ & $\begin{array}{c}-0.001 \\
(0.001)\end{array}$ \\
\hline Log GDP per capita $\mathbf{t}_{\mathbf{1}-\mathbf{1}}$ & $\begin{array}{c}1.969 * * * \\
(0.701)\end{array}$ & $\begin{array}{c}0.655 \\
(1.514)\end{array}$ & $\begin{array}{l}-1.167 \\
(2.267)\end{array}$ & $\begin{array}{c}1.204 \\
(1.703)\end{array}$ & $\begin{array}{c}1.291 \\
(2.309)\end{array}$ & $\begin{array}{c}0.075 \\
(0.141)\end{array}$ \\
\hline $\log \operatorname{IIR}_{t-1}$ & $\begin{array}{c}0.597 \\
(0.915)\end{array}$ & $\begin{array}{l}-0.601 \\
(2.567)\end{array}$ & $\begin{array}{c}2.568 \\
(2.706)\end{array}$ & $\begin{array}{c}1.397 \\
(3.786)\end{array}$ & $\begin{array}{c}3.54 \\
(2.874)\end{array}$ & $\begin{array}{c}0.166 \\
(0.166)\end{array}$ \\
\hline Inflation $_{\mathbf{t}-1}$ & $\begin{array}{c}0.042 * * \\
(0.033)\end{array}$ & $\begin{array}{l}-0.012 \\
(0.113)\end{array}$ & $\begin{array}{c}0.014 \\
(0.106)\end{array}$ & $\begin{array}{c}0.057 \\
(0.093)\end{array}$ & $\begin{array}{l}-0.025 \\
(0.141)\end{array}$ & $\begin{array}{l}-0.001 \\
(0.006)\end{array}$ \\
\hline Log Gold price $_{t-1}$ & $\begin{array}{c}-1.014 * * \\
(0.506)\end{array}$ & $\begin{array}{c}0.033 \\
(0.792)\end{array}$ & $\begin{array}{c}0.118 \\
(0.939)\end{array}$ & $\begin{array}{c}0.534 \\
(0.761)\end{array}$ & $\begin{array}{c}-0.891 \\
(1.177)\end{array}$ & $\begin{array}{c}0.001 \\
(0.080)\end{array}$ \\
\hline Change in REER $\mathrm{t}_{\mathrm{t}-1}$ & & & & & $\begin{array}{c}0.026 \\
(0.061)\end{array}$ & \\
\hline Constant & & $\begin{array}{l}-4.756 \\
(7.566) \\
\end{array}$ & $\begin{array}{c}-4.175 \\
(11.285)\end{array}$ & $\begin{array}{l}-18.548^{*} \\
(10.225)\end{array}$ & $\begin{array}{c}-21.301 * * * \\
(7.695)\end{array}$ & $\begin{array}{c}-1.374 * * * \\
(0.521)\end{array}$ \\
\hline No of countries & 100 & 100 & 93 & 85 & 63 & 100 \\
\hline No. of obs. & 1,767 & 1,647 & 958 & 856 & 1,203 & 1813 \\
\hline No. of instruments & & 47 & 50 & 53 & 43 & 70 \\
\hline Hansen statistic & & 40.392 & 44.589 & 53.07 & 35.686 & 69.607 \\
\hline $\operatorname{AR}(2)$ statistic & & 0.757 & -0.203 & -0.423 & -0.2 & 0.11 \\
\hline Wald Chi-square & & $263.976 * * *$ & $370.614 * * *$ & $332.517 * * *$ & $550.406 * * *$ & $1239.199 * * *$ \\
\hline
\end{tabular}

Notes: Column 5 has only 63 countries given the data availability of REER. The dependent variable is gold as a share of overall central bank reserves. Regressions are estimated using the systerm generalized methods of moments (SGMM) method with a collapsed instrument set. Heteroskedasticity and autocorrelation-robust Windmeijer-corrected standard errors are reported in parentheses. All regressions pass the Hansen test of over-identifying restrictions and the Arellano-Bond test for AR(2). *** Significant at $1 \%, * *$ significant at $5 \%$ and $*$ significant at $10 \%$.

We also test the baseline specification by adding one more control for a change in REER in column (5). If the change is REER is positive indicating a real appreciation of the domestic currency, the central bank will have more capacity to buy gold which will gold more affordable in real terms. While this effect is not significant, the coefficient is positive indicating a positive relationship between appreciation in domestic currency and gold to total reserves. The sample size for this specification drops considerably given that the information on REER changes is 
available only across 63 countries; however, the results are in line with baseline SGMM results.

The final robustness test is by taking gold holdings as a percentage of GDP as the dependent variable as used in Aizenman and Inoue (2013). Our finding (as indicated in column (6)) on the sensitivity of the gold holdings to global risk indicator is significant and consistent with the findings from our baseline specification. Although the sensitivity changes with the specific robustness test, the overall results are unaffected.

\section{Conclusion}

Our study on the sensitivity of central banks' gold holdings (as a share of overall reserves) to global risk finds that this effect is positive and statistically significant after controlling for factors such as economic size, financial development, country ratings, and gold price. We find evidence that high-income countries have a relatively higher sensitivity than developing countries, possibly due to better reserve risk management by their central banks.

We also find evidence that gold reserves as a percentage of overall reserves are more responsive to global risk especially when other indicators suggest higher external vulnerability. These findings suggest that central banks adjust their gold holdings in response to changes in global

risk conditions, with the magnitude of response depending on reserve-management capacity and country-specific vulnerabilities. This study reiterates the importance of gold as a hedge against potential vulnerabilities faced by an economy. 


\section{References}

Aizenman, J., \& Inoue, K. (2013). Central banks and gold puzzles. Journal of the Japanese and International Economies, 28, 69-90. http://doi.org/10.1016/j.jjie.2013.02.001

Aizenman, J., \& Lee, J. (2008). Financial versus Monetary Mercantilism: Long-run View of Large International Reserves Hoarding. The World Economy, 31(5), 593-611.

Arellano, M., \& Bond, S. (1991). Some Tests of Specification for Panel Data: Monte Carlo Evidence and an Application to Employment Equations. The Review of Economic Studies , 58 (2 ), 277-297. http://doi.org/10.2307/2297968

Arellano, M., \& Bover, O. (1995). Another look at the instrumental variable estimation of errorcomponents models. Journal of Econometrics, 68(1), 29-51. http://doi.org/10.1016/03044076(94)01642-D

Bacchetta, P., \& Van Wincoop, E. (2013). Sudden spikes in global risk. Journal of International Economics, 89(2), 511-521. http://doi.org/10.1016/j.jinteco.2012.07.006

Bampinas, G., \& Panagiotidis, T. (2015). Are gold and silver a hedge against inflation? A two century perspective. International Review of Financial Analysis, 41, 267-276. http://doi.org/10.1016/j.irfa.2015.02.007

Baur, D. G. (2016). Central Banks and Gold. Available at SSRN:2326606. http://doi.org/http://dx.doi.org/10.2139/ssrn.2326606

Baur, D. G., \& Lucey, B. M. (2010). Is Gold a Hedge or a Safe Haven? An Analysis of Stocks, Bonds and Gold. Financial Review, 45(2), 217-229. http://doi.org/10.1111/j.1540$6288.2010 .00244 . \mathrm{x}$

Baur, D. G., \& McDermott, T. K. (2010). Is gold a safe haven? International evidence. Journal 
of Banking and Finance, 34(8), 1886-1898. http://doi.org/10.1016/j.jbankfin.2009.12.008

Beckmann, J., Berger, T., \& Czudaj, R. (2015). Does gold act as a hedge or a safe haven for stocks? A smooth transition approach. Economic Modelling, 48, 16-24. http://doi.org/10.1016/j.econmod.2014.10.044

Benigno, G., \& Fornaro, L. (2012). Reserve Accumulation, Growth and Financial Crises. CEP Discussion Paper, (1161), 1-36. Retrieved from http://papers.ssrn.com/sol3/papers.cfm?abstract_id=2210193

Bredin, D., Conlon, T., \& Poti, V. (2015). Does gold glitter in the long-run? Gold as a hedge and safe haven across time and investment horizon. International Review of Financial Analysis, 41,320-328. http://doi.org/10.1016/j.irfa.2015.01.010

Bruno, G. S. F. (2005). Approximating the bias of the LSDV estimator for dynamic unbalanced panel data models. Economics Letters, 87(3), 361-366. http://doi.org/10.1016/j.econlet.2005.01.005

Bruno, V., \& Shin, H. S. (2015). Capital flows and the risk-taking channel of monetary policy. Journal of Monetary Economics, 71, 119-132. http://doi.org/10.1016/j.jmoneco.2014.11.011

Bussière, M., Cheng, G., Chinn, M. D., \& Lisack, N. (2015). For a few dollars more: Reserves and growth in times of crises. Journal of International Money and Finance, 52, 127-145. http://doi.org/10.1016/j.jimonfin.2014.11.016

Chen, K.-H., Lee, J.-M., \& You, C.-H. (2014). Who upholds the surging gold price? The role of the central bank worldwide. Applied Economics, 46(April), 2557-2575. http://doi.org/10.1080/00036846.2014.904495 
Cheng, G. (2015). A Growth Perspective of Foreign Reserve Accumulation. Macroeconomic Dynamics, 19(6), 1358-1379. http://doi.org/10.1017/S1365100513000862

Chinn, M. D., \& Ito, H. (2006). What matters for financial development? Capital controls, institutions, and interactions. Journal of Development Economics, 81(1), 163-192. http://doi.org/10.1016/j.jdeveco.2005.05.010

Ciarlone, A., Piselli, P., \& Trebeschi, G. (2009). Emerging markets' spreads and global financial conditions. Journal of International Financial Markets, Institutions and Money, 19(2), 222239. http://doi.org/10.1016/j.intfin.2007.11.003

Dempster, N., \& Artigas, J. C. (2009). Gold as a tactical inflation hedge and Long term Strategic Asset. World Gold Council Research Paper, (333).

Eichengreen, B. (2005). Sterling's past, dolloar's future: historical perspectives on reserve currency competition. NBER Working Paper 11336. http://doi.org/10.3386/w11336

Emmrich, O., \& McGroarty, F. J. (2013). Should gold be included in institutional investment portfolios. Applied Financial Economics, 23(19), 1553-1565. http://doi.org/10.1080/09603107.2013.839858

European Central Bank. (2004). Risk Management for Central Bank Foreign Reserves. (C. Bernadell, P. Cardon, J. Coche, F. Diebold, \& S. Manganelli, Eds.). European Central Bank.

Garcia, H. A., Ortiz, A., \& Cowan, K. (2006). The Role of Global Risk Aversion in Explaining Sovereign Spreads. Economia, 7(1), 125-155. Retrieved from http://www.jstor.org/stable/20065508

Ghosh, A. (2016). Determinants of Gold Demand in Reserve Bank of India' s foreign exchange. Economics Bulletin, 36(4), 1929-1937. 
Jubinski, D., Lipton, A. F., \& Joseph, S. (2013). VIX , Gold , Silver , and Oil : How do Commodities React to Financial Market Volatility? Journal of Accounting and Finance, 13(1), 70-89.

Lane, P. R., \& Burke, D. (2001). The Empirics of Foreign Reserves. Open Economies Review, 12(4), 423-434. http://doi.org/10.1023/A:1017939118781

Marc-Andre, G., \& Parent, N. (2005). An Empirical Analysis of Foreign Exchange Reserves in Emerging Asia (No. Bank of Canada Working Paper 2005-38). Working paper 2005-38.

Miranda-Agrippino, S., \& Rey, H. (2015). World Asset Markets and the Global Financial Cycle.

Nickell, S. (1981). Biases in Dynamic Models with Fixed Effects. Econometrica, 49(6), 14171426. http://doi.org/10.2307/1911408

Nier, E., Saadi Sedik, T., \& Mondino, T. (2014). Gross Private Capital Flows to Emerging Markets: Can the Global Financial Cycle Be Tamed? IMF Working Papers, 14(196), 1. http://doi.org/10.5089/9781498351867.001

O’Connor, F. a., Lucey, B. M., Batten, J. a., \& Baur, D. G. (2015). The financial economics of gold - A survey. International Review of Financial Analysis, 41, 186-205. http://doi.org/10.1016/j.irfa.2015.07.005

Obstfeld, M., Shambaugh, J. C., \& Taylor, A. M. (2009). Financial Instability, Reserves, and Central Bank Swap Lines in the Panic of 2008. NBER Working Paper 14826. Retrieved from http://www.nber.org/papers/w14826

Officer, L. H. (2010). Gold Standard BT - Monetary Economics. In S. N. Durlauf \& L. E. Blume (Eds.), (pp. 96-107). London: Palgrave Macmillan UK. http://doi.org/10.1057/9780230280854_12 
Oktay, B., Öztunç, H., \& Serİn, Z. V. (2016). Determinants of Gold Reserves : An Empirical Analysis for G-7 Countries, 38(October 2015), 8-16. http://doi.org/10.1016/S2212$5671(16) 30172-1$

Reinhart, C., \& Calvo, G. (2000). When Capital Inflows Come to a Sudden Stop: Consequences and Policy Options. Reforming the International Monetary and Financial System, (6982), 175-201. Retrieved from http://mpra.ub.uni-muenchen.de/6982/

Roodman, D. (2009). How to do xtabond2: An introduction to difference and system GMM in Stata. Stata Journal, 9(1), 86-136. http://doi.org/The Stata Journal

Rossi, S. (2013). Post-crisis challenges to central bank independence. The LBMA/LPPM Precious Metals Conference, (September), 1-10.

Roveda, C., \& Rosselli, F. (2003). The Ratio of International Reserves to Short Term External Debt as an Indicator of External Vulnerability: Some Lessons from the Experience of Mexico and Other Eemerging Economies.

Sari, R., Soytas, U., \& Hacihasanoglu, E. (2011). Do global risk perceptions influence world oil prices? Energy Economics, 33(3), 515-524. http://doi.org/10.1016/j.eneco.2010.12.006

Svirydzenka, K. (2016). Introducing a New Broad-based Index of Financial Development. IMF Working Paper, (5).

World Gold Council. (2016). Gold : valuable reserve amid unprecedented policy environment. Retrieved from http://www.gold.org/research/gold-valuable-reserve-amid-unprecedentedpolicy-environment 


\section{Appendix table 1: Countries}

\begin{tabular}{|c|c|c|}
\hline \multicolumn{3}{|l|}{ High-income countries } \\
\hline$\overline{\text { Australia }}$ & France & \\
\hline Austria & United Kingdom & Malta \\
\hline Belgium & Greece & Norway \\
\hline Bahrain, Kingdom of & China, P.R.: Hong Kong & Oman \\
\hline Canada & Hungary & Poland \\
\hline Switzerland & Ireland & Portugal \\
\hline Chile & Iceland & Saudi Arabia \\
\hline Cyprus & Israel & Singapore \\
\hline Czech Republic & Italy & Slovak Republic \\
\hline Germany & Japan & Slovenia \\
\hline Denmark & Korea, Republic of & Sweden \\
\hline Spain & Kuwait & Trinidad and Tobago \\
\hline Estonia & Lithuania & Uruguay \\
\hline Finland & Latvia & United States \\
\hline \multicolumn{3}{|l|}{ Developing countries } \\
\hline$\overline{\text { Albania }}$ & India & \\
\hline Argentina & Iraq & Nepal \\
\hline Burundi & Jordan & Pakistan \\
\hline Bangladesh & Kazakhstan & Peru \\
\hline Bulgaria & Kenya & Philippines \\
\hline Belarus & Kyrgyz Republic & Papua New Guinea \\
\hline Bolivia & Cambodia & Paraguay \\
\hline Brazil & Lao People's Democratic Republic & Romania \\
\hline China, P.R.: Mainland & Libya & Russian Federation \\
\hline Cameroon & Sri Lanka & El Salvador \\
\hline Congo, Republic of & Morocco & Suriname \\
\hline Colombia & Mexico & Thailand \\
\hline Costa Rica & Macedonia, FYR & Tunisia \\
\hline Ecuador & Mongolia & Turkey \\
\hline Egypt & Mozambique & Ukraine \\
\hline Fiji & Mauritius & Venezuela \\
\hline Ghana & Malawi & Vietnam \\
\hline Guatemala & Malaysia & Yemen, Republic of \\
\hline Honduras & Nigeria & South Africa \\
\hline Indonesia & Nicaragua & Zimbabwe \\
\hline
\end{tabular}

